\title{
Preparation of Co-Gr Nanocomposites and Analysis of Their Tribological and Corrosion Characteristics
}

\author{
G. R. Raghav, A. N. Balaji, D. Muthukrishnan, and V. Sruthi* \\ K.L.N. College of Engineering, \\ 630612 Pottapalayam, Sivagangai District, Tamil Nadu, India \\ "SCMS School of Engineering and Technology, \\ Vidya Nagar, Palissery, Karukutty, Ernakulam, \\ 683582 Kerala, India
}

This work summarizes the tribological and corrosion behaviour of $\mathrm{Co}-\mathrm{Gr}$ nanocomposites. The $\mathrm{Co}-\mathrm{Gr}$ nanocomposites are synthesized using highenergy ball mill and compacted into cylindrical pellets by hydraulic pressing. The composites are characterized using SEM, EDAX, and AFM. The dry sliding wear results reveal that the wear resistance increases with increase in the percentage of graphite ( $\mathrm{Gr})$. The corrosion characteristics of the $\mathrm{Co}-\mathrm{Gr}$ nanocomposites are examined using immersion and electrochemical methods. The electrochemical polarization results reveal the increase in corrosion resistant of the $\mathrm{Co}-25 \mathrm{Gr}$ nanocomposites $\left(E_{\text {corr }}=-0.416 \mathrm{~V} v s \mathrm{Ag} / \mathrm{AgCl}\right)$ to more positive side than pure Co $(-0.443 \mathrm{~V})$. Electrochemical impedance spectroscopy analysis results also confirmed $\mathrm{Co}-25 \mathrm{Gr}$ nanocomposite has higher resistance value $(100 \Omega)$. The results of the weight loss method also authenticate increase in corrosion resistance of $\mathrm{Co}-25 \mathrm{Gr}$ nanocomposite.

Key words: wear, corrosion, EDAX, SEM, AFM.

У роботі представлено узагальнюючі результати досліджень трибологічної та корозійної поведінки нанокомпозитів Co-Gr. Нанокомпозити $\mathrm{Co}_{-}$ Gr було синтезовано з використанням високоенергетичного кульового млина та скомпактовано у циліндричні гранули шляхом гідравлічного пресування. Композити досліджено за допомогою СЕМ, ЕДС та АCM. Показано, що в результаті сухого ковзання опір зношуванню зростає зі збі-

Corresponding author: A. N. Balaji

E-mail: balajime@yahoo.com

Citation: G. R. Raghav, A. N. Balaji, D. Muthukrishnan, and V. Sruthi, Preparation of Co-Gr Nanocomposites and Analysis of Their Tribological and Corrosion Characteristics, Metallofiz. Noveishie Tekhnol., 40, No. 7: 979-992 (2018), DOI: $10.15407 /$ mfint.40.07.0979. 
льшенням процентного вмісту графіту (Gr). Також досліджено корозійні характеристики нанокомпозитів Co-Gr з використанням імерсійних та електрохемічних метод. Результати електрохемічної поляризації показали підвищення корозійної стійкости нанокомпозитів $\mathrm{Co}-25 \mathrm{Gr}$ $\left(E_{\text {corr }}=-0,416\right.$ В у зіставленні з $\left.\mathrm{Ag} / \mathrm{AgCl}\right)$; значення відповідного потенціялу зміщене у позитивному напрямку відносно чистого Сo $(-0,443 \mathrm{~B})$. $\mathrm{Pe}$ зультати аналізи електрохемічної імпедансної спектроскопії також підтвердили, що нанокомпозит Сo-25Gr має вище значення електроопору (100 Ом). Результати, одержані методою визначення втрати ваги, також підтвердили зростання корозійної стійкости нанокомпозиту Co-25Gr.

Ключові слова: знос, корозія, ЕДС, СЕМ, АСМ.

В работе представлены обобщающие результаты исследования трибологического и коррозионного поведения нанокомпозитов Co-Gr. Нанокомпозиты Co-Gr были синтезированы с использованием высокоэнергетической шаровой мельницы и скомпактированы в цилиндрические гранулы путём гидравлического прессования. Композиты были исследованы с помощью СЭМ, ЭДС и АСМ. Показано, что в результате сухого скольжения сопротивление износу возрастает с увеличением процентного содержания графита (Gr). Также исследованы коррозионные характеристики нанокомпозитов Сo-Gr с использованием иммерсионных и электрохимических методов. Результаты электрохимической поляризации показали увеличение коррозионной устойчивости нанокомпозитов $\mathrm{Co}-25 \mathrm{Gr}$ $\left(E_{\text {corr }}=-0,416\right.$ В в сопоставлении с $\left.\mathrm{Ag} / \mathrm{AgCl}\right)$; значение соответствующего потенциала смещено в положительном направлении относительно чистого Co $(-0,443$ В). Результаты анализа электрохимической импедансной спектроскопии также подтвердили, что нанокомпозит Co-25Gr имеет более высокое значение электросопротивления (100 Ом). Результаты, полученные методом определения потери веса, также подтвердили увеличение коррозионной стойкости нанокомпозита $\mathrm{Co}-25 \mathrm{Gr}$.

Ключевые слова: износ, коррозия, ЭДС, СЭМ, АСМ.

(Received April 2, 2018)

\section{INTRODUCTION}

The materials used for dental prostheses and orthopaedic implants should have high corrosion resistance, wear resistance and high mechanical strength. The cobalt is such kind of material, which is basically used in orthopaedic and dental applications because of their improved resistances together with formability $[1,2]$.

The dental implants are of two different types such as permanent or removable framework structures [3]. In order to improve the corrosion and wear resistance of cobalt, $\mathrm{Cr}, \mathrm{Ni}$ and Mo are normally added as reinforcement $[4,5]$. However, the addition of these materials not only improves the strength and properties of alloy but also increases the 
toxicity, which in turn has an adverse effect [6].

Graphite reinforced composites are a potential replacement for materials such as $\mathrm{Cr}, \mathrm{Mo}$, etc. [7]. Graphite is a biodegradable and biocompatible material with good physical and mechanical properties [8, 9]. The mechanical and physical properties of bulk composites can be further improved by reinforcement of nanoparticle with base materials [10, 11].

Although there are a few previous studies focused on mechanical and tribological properties of Co-based alloys [3], the study on the effect of reinforcement of nanographite in cobalt matrix is unexplored up to the author's knowledge.

In this study, the $\mathrm{Co}-\mathrm{Gr}$ nanocomposites are fabricated by a combination of powder metallurgy and hydraulic pressing process. The composites are obtained in various proportions. The dry sliding wear and electrochemical corrosion characteristics of the composites are studied in detail. The results of the studies are expected to substantiate the application of Co-graphite nanocomposites in dental and orthopaedic implants.

\section{MATERIALS and METHODS}

\subsection{Materials and Preparation of Composite Materials}

The Co and $\mathrm{Gr}$ powders used in this work were of research grade having a purity level of $99.5 \%$ and $99 \%$ respectively. The nanographite powders were synthesized using high-energy ball mill (Fritsch pulverisette, Germany), $40 \mathrm{~g}$ of graphite powder and nearly $800 \mathrm{~g}$ of WC (50 balls). The powder to ball weight ratio was maintained at 1:20 and the ball milling process was carried out for $5 \mathrm{~h}$ in order to achieve nanographite. The $\mathrm{Co}-\mathrm{Gr}$ nanocomposites of different weight proportions $(95: 05,90: 10,85: 15,80: 20$, and $75: 25)$ were prepared by mixing in a high-energy ball mill. The composite powder was then directly fed into a cylindrical die of $8 \mathrm{~mm}$ diameter and $50 \mathrm{~mm}$ height and compacted into a cylindrical pellet of height $20 \mathrm{~mm}$ by applying a load of $0.5 \mathrm{GPa}$ in a hydraulic press and sintered at the temperature of $600^{\circ} \mathrm{C}$ for 1 hour in order to harden the green compact into composite pellets.

\subsection{Characterization}

The surface topography of $\mathrm{Co}-\mathrm{Gr}$ nanocomposites was studied using Atomic Force Microscopy (XE70, Park System, South Korea) in a noncontact mode using a $\mathrm{Si}_{3} \mathrm{~N}_{4}$ tip having a radius of curvature of less than $10 \mathrm{~mm}$. The scan size and constant are $10 \times 10 \mu \mathrm{m}$ and $40 \mathrm{~N} / \mathrm{m}$ respectively. The morphological characterization of the composite was done using SEM (Hitachi SU1510, Secondary Electron Mode, $10 \mathrm{kV}$, the emission current of $96 \mu \mathrm{A}$ ). The compositional analysis was studied using EDX (QUANTAX-Bruker). 


\subsection{Pin on Disc Dry Sliding Wear Test}

The Co-Gr nanocomposite pellets of $8 \mathrm{~mm}$ diameter and length of $20 \mathrm{~mm}$ are used as the test sample. The test was done using pin on disc apparatus (DUCOM, Bangalore) according to ASTM: G99 standards. The disc selected for the experiment was EN31 steel. The composite sample and the disc were cleaned to remove impurities using acetone before the test starts. The wear test was carried out at various load ranges such as $5,10,15$, and $20 \mathrm{~N}$ and at varying sliding distant from $500 \mathrm{~m}$ to $2000 \mathrm{~m}$ [8]. The sliding speed is also varied from $0.5 \mathrm{~m} / \mathrm{s}$ to $2 \mathrm{~m} / \mathrm{s}$. The initial and final weights of the composite specimens were measured using an electronic weighing scale so as to determine the weight loss of the specimens $[12,13]$.

\subsection{Potentiometric Polarization Test}

The potentiometric polarization test was used to investigate the electrochemical corrosion behaviour of $\mathrm{Co}-\mathrm{Gr}$ nanocomposites. The potentiometric tests were studied using Biologic SP-150 potentiostat controlled using the EC-Lab®software. The experiments were performed using three electrode cell consists of platinum wire counter electrode $\mathrm{Ag} / \mathrm{AgCl}$ reference electrode and the $\mathrm{Co}-\mathrm{Gr}$ nanocomposite pellet as a working electrode. The polarization tests were carried out at $25^{\circ} \mathrm{C}$ with the $1 \mathrm{~N} \mathrm{H}_{2} \mathrm{SO}_{4}$ solution. The composite pellets were polished with emery paper and rinsed with acetone and double distilled water prior to the electrochemical tests. The $\mathrm{Co}-\mathrm{Gr}$ nanocomposite pellets, which were used as working electrode, were immersed in the electrolyte solution of $1 \mathrm{~N} \mathrm{H}_{2} \mathrm{SO}_{4}$ for $1 \mathrm{~h}$. in order to reach steady state condition, and the OCP was measured. The potentiometric polarization curves were obtained at the scan rate of $5 \mathrm{mV} / \mathrm{s}$. The corrosion potential $E_{\text {corr }}$ and current density $I_{\text {corr }}$ were obtained using EC lab software through Tafel fit extrapolation $[4,14,15]$.

\subsection{Electrochemical Impedance Spectroscopy}

The electrochemical impedance spectroscopy (EIS) for the composites was performed at the range of $100 \mathrm{kHz}$ to $100 \mathrm{MHz}$ and the initial sinusoidal voltage signal was $10 \mathrm{mV}$. The experiments were carried out using Biologic SP-150 electrochemical workstation against open circuit potential. The EIS data were then fitted and analysed using the EC-lab software [14, 16-18].

\subsection{Immersion Test}

The weight loss of the Co-Gr nanocomposite in the various corrosive 
mediums was studied, and the percentage of weight loss is calculated. The corrosive medium such as $0.1 \mathrm{~N}$ and $0.5 \mathrm{~N} \mathrm{HCl}, \mathrm{H}_{2} \mathrm{SO}_{4}$ and $10 \%$ $\mathrm{NaCl}$ were used for this purpose. The $\mathrm{Co}-\mathrm{Gr}$ nanocomposite pellets are immersed in each of the above-mentioned electrolytic solutions for $24 \mathrm{~h}$. After that, the samples were removed from the solutions, washed with distilled water, and dried at room temperature, and the changes in weight of the composites were used to calculate the percentage weight loss [19].

\section{RESULTS AND DISCUSSION}

\subsection{SEM Analysis}

Figure 1, $a$ and $b$ shows the surface morphology and EDAX spectrum of Co-Gr nanocomposites. The SEM image clearly reveals the homogeneous mixture of $\mathrm{Co}-\mathrm{Gr}$ nanocomposites. The EDAX spectrum confirms the presence of cobalt and graphite in the composite material. The particle size of $\mathrm{Co}$ and $\mathrm{Gr}$ were found to be in the range of 10 microns and 80-150 $\mathrm{nm}$ respectively. The Gr nanoparticles were found to be agglomerated.

Figure 2 shows the surface morphology of Co-Gr composite pellets before the test, which shows the uniform dispersion of $\mathrm{Gr}$ in $\mathrm{Co}^{-}$ matrix.

Figure 3, $a$ and $b$ reveals the worn out surfaces of the pure Co and

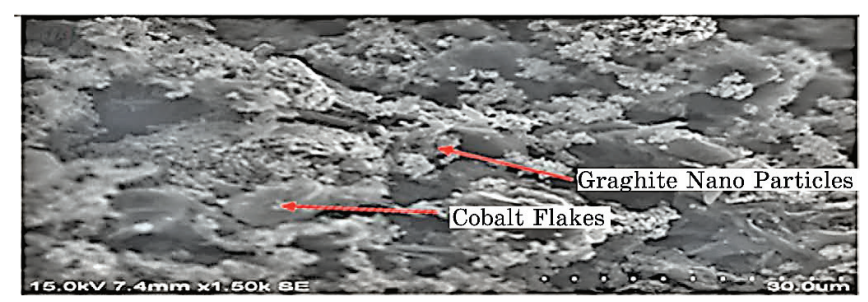

$a$

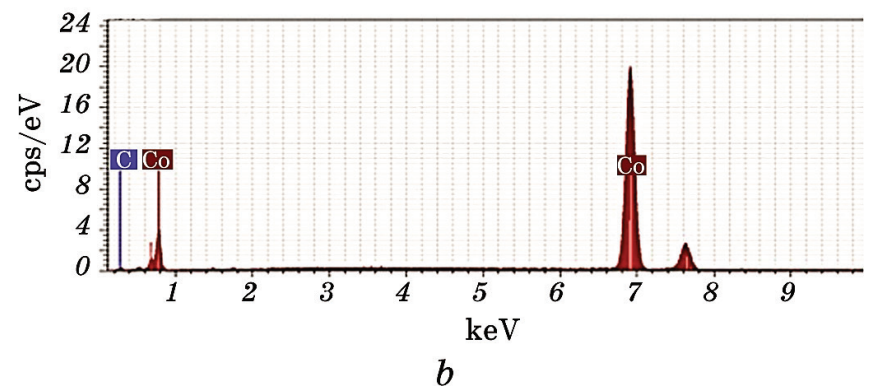

Fig. 1. SEM image ( $a$ ) and EDAX spectrum $(b)$ of Co-Gr nanocomposite. 


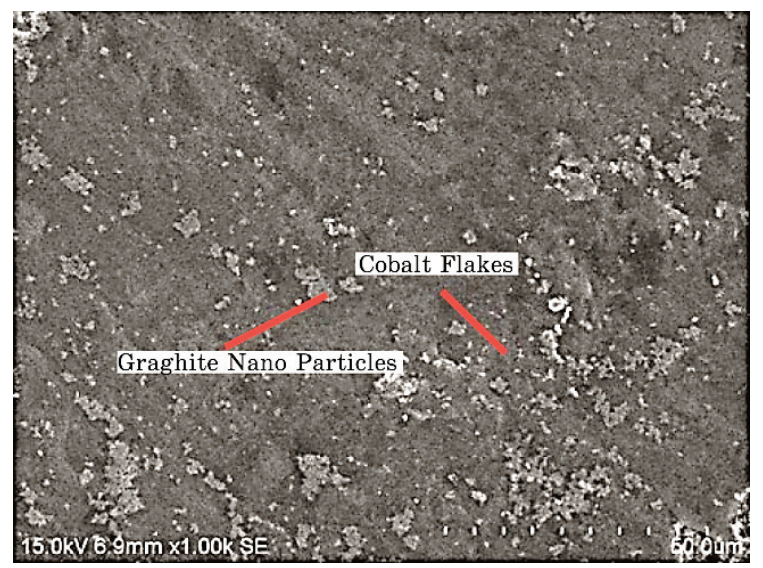

Fig. 2. SEM micrograph of Co-25Gr nanocomposite pellets before wear test.

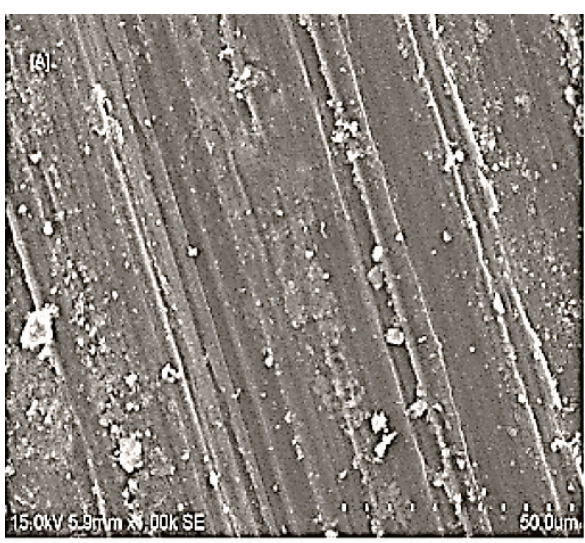

$a$

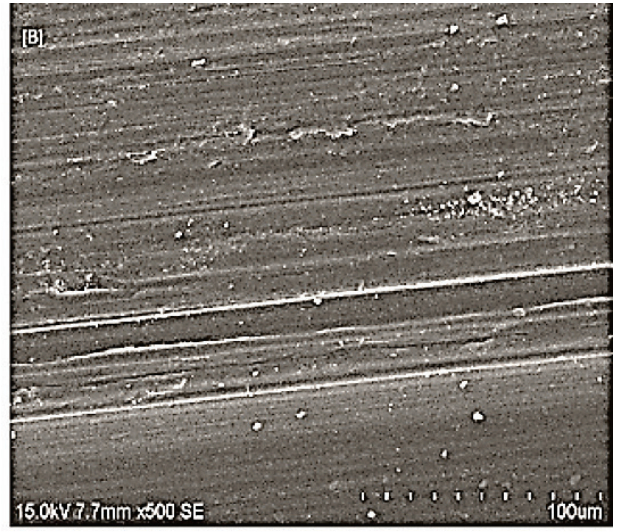

$b$

Fig. 3. SEM micrograph of pure Co $(a)$ and Co-25Gr nanocomposite $(b)$ pellets after wear test.

composite pellets after sliding wear test. The scratches and grooves were formed in the direction of sliding which confirms the mechanism of wear due to abrasive wear between the composite pellet and rotating disc. The SEM micrograph shows very less change in the subsurface microstructure of the Co-Gr pellets as compared to pure Co, which attributes to the improved wear resistance because of nanographite reinforcement.

\subsection{AFM Analysis}

Surface topography of the composite materials was evaluated using 

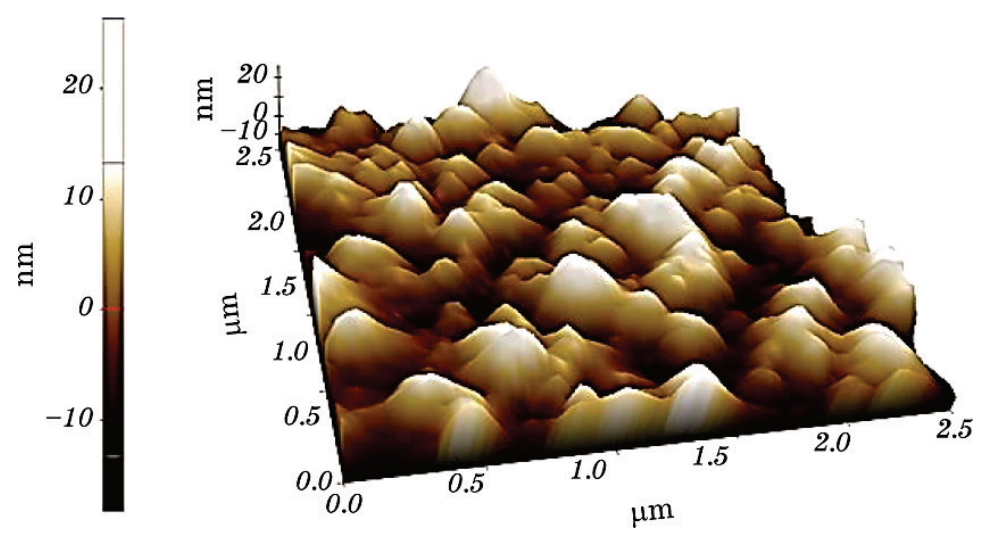

Fig. 4. 3D AFM image of $\mathrm{Co}-25 \mathrm{Gr}$ nanocomposite.
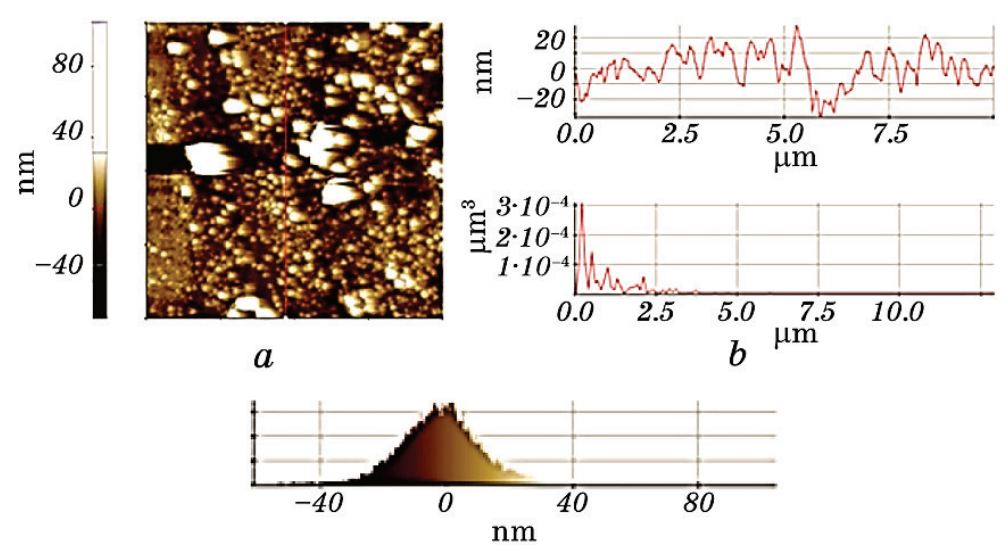

c

Fig. 5. $2 D$ AFM image (a), line profile analysis $(b)$ and histogram $(c)$ of $\mathrm{Co}^{-}$ $25 \mathrm{Gr}$ nanocomposite.

AFM.

Figure 4, the 3D AFM image shows the height and width of the composite materials which is found to be around $10-20 \mathrm{~nm}$ and $500 \mathrm{~nm}$ respectively. Figure 5, $a-c$ are $2 D$ AFM image and its corresponding line diagram and histogram. The AFM $2 D$ analysis also confirms that the particle height is in the range of $10-20 \mathrm{~nm}$.

\subsection{Sliding Wear Analysis}

The wear analysis is done using pin-on-disc apparatus for the study of tribological characteristics of novel $\mathrm{Co}-\mathrm{Gr}$ nanocomposites. From Figure 6, we can learn that the addition of Gr nanoparticles decreases the 


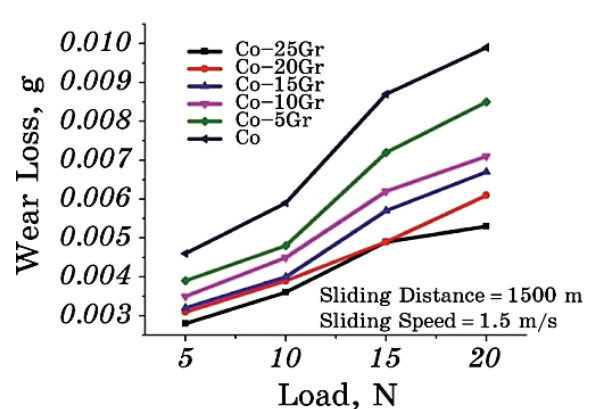

$a$

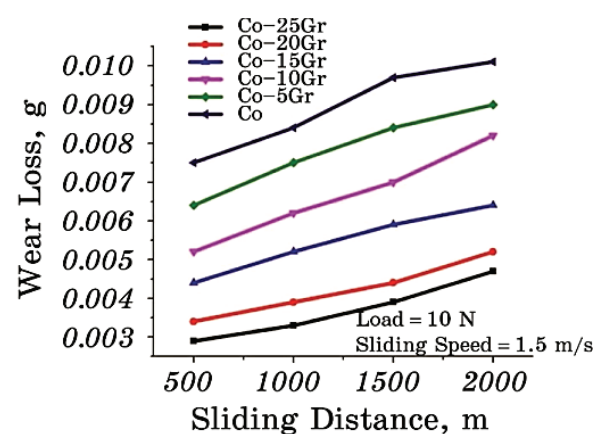

b

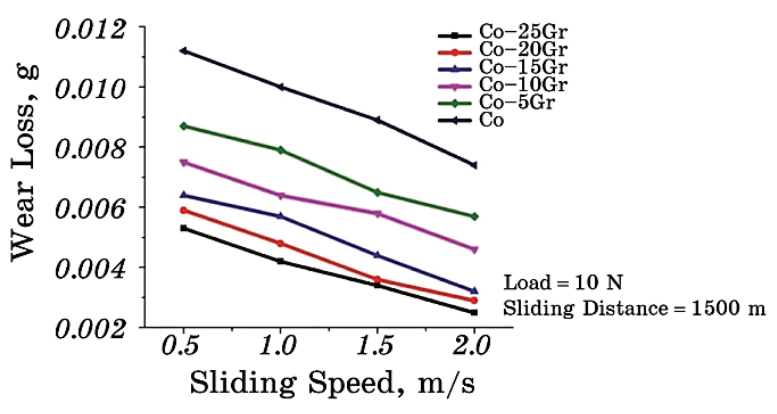

$c$

Fig. 6. Wear loss of Co and Co-Gr nanocomposite: applied load (a), sliding distance $(b)$, sliding speed $(c)$.

wear loss of the composites as compared to that of pure Co pins. The results reveal that increase in the percentage of nanographite in $\mathrm{Co}-$ matrix has further increased the wear resistance. The Co-25Gr nanocomposites have lesser wear loss than Co-5Gr. Figure 6, $a$ shows the wear loss incurred by specimens at various loads ranging from $5 \mathrm{~N}$ to $20 \mathrm{~N}$. From the graphs, it is evident that the $\mathrm{Co}-\mathrm{Gr}$ composites have higher wear resistance at different loads but the wear loss increases with increase in load, this may be due to softening of composites due to increase in temperature at the interface. The wear loss phenomenon ranging from $500 \mathrm{~m}$ to $2000 \mathrm{~m}$ is shown in Fig. 6, $b$. It can be noted that increase in $\mathrm{Gr}$ in nanocomposites decreases the wear loss, which may be due to the lubricating effect of nanographite reinforcements. Figure 6, $c$ represents the trend of wear loss of composite materials at various sliding speed. From this figure, it is clear that the wear loss decreases with increase in sliding speed.

\subsection{Coefficient of Friction Analysis (COF)}

Figure 7 shows the various trends of coefficient of friction of $\mathrm{Co}-\mathrm{Gr}$ 


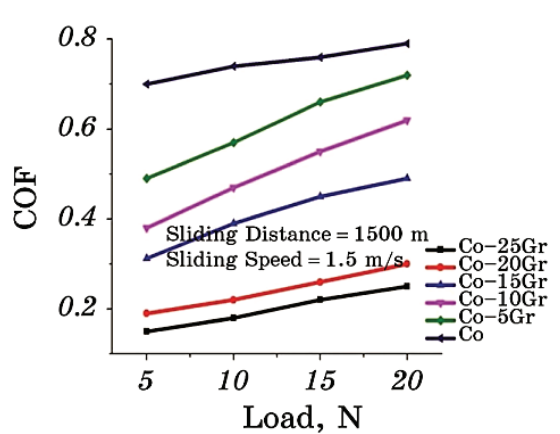

$a$

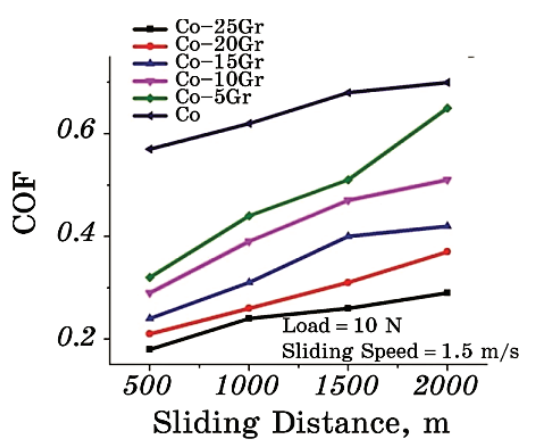

$b$

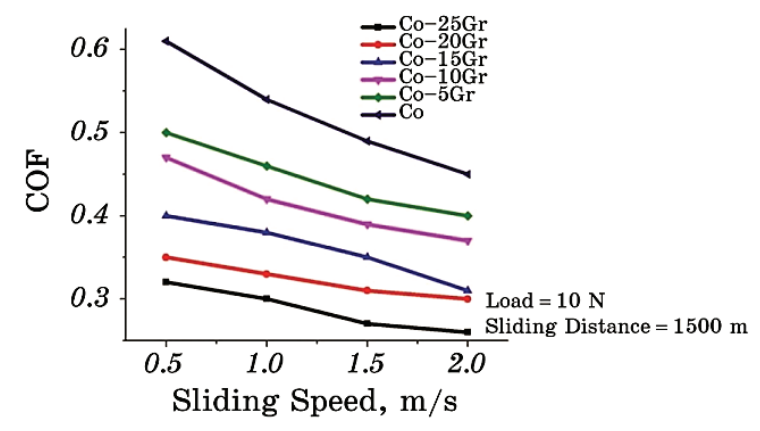

$c$

Fig. 7. COF of Co and Co-Gr nanocomposite: applied load (a), sliding distance (b), sliding speed (c).

nanocomposites. The COF decreases with increase in nanographite content; this is because of the lubricating property of nanographite particles, which improves the self-lubricating capacity of the composites.

The results utter that the $\mathrm{COF}$ of $\mathrm{Co}-25 \mathrm{Gr}$ nanocomposite is lower compared to that of pure cobalt pellet. The coefficient of friction of composite specimens is shown in Fig. 7, $a$, which reveals that the COF of the pure cobalt and composite pellets increases with an increase in load.

From Figure 7, $b$, it is evident that the COF values of pure Co and $\mathrm{Co}-\mathrm{Gr}$ nanocomposites are relatively low when the sliding distance is less and the COF further increases with an increase in sliding distance. The evaluation of Fig. 7, $c$ dictates there is a linear decrement in COF values with increase in sliding speed.

\subsection{Potentiometric Polarization Analysis}

The potentiometric polarization analyses of the pure cobalt and various compositions of $\mathrm{Co}-\mathrm{Gr}$ nanocomposites in $5 \%$ wt. $\mathrm{NaCl}$ solution is plotted in Fig. 8; the graphs are plotted against potential voltage and current density. The composite materials show stable passive region 


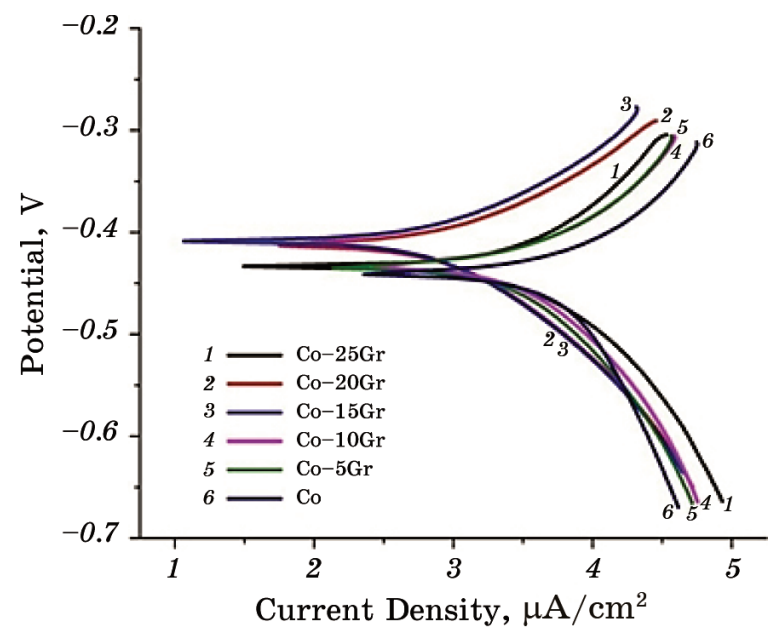

Fig. 8. Potentiometric polarization curves of $\mathrm{Co}$ and $\mathrm{Co}-\mathrm{Gr}$ nanocomposites.

TABLE 1. Corrosion characteristics of the pure $\mathrm{Co}$ and $\mathrm{Co}-\mathrm{Gr}$ nanocomposites.

\begin{tabular}{c|c|c|c|c}
\hline No & Specimen & $E_{\text {corr }}, \mathrm{V}$ & $\begin{array}{c}I_{\text {corr }} \cdot 10^{-3}, \\
\mu \mathrm{A} / \mathrm{cm}^{2}\end{array}$ & $\begin{array}{c}\text { Polarization resistance } R_{P}, \\
\Omega \cdot \mathrm{cm}^{2}\end{array}$ \\
\hline 1 & Pure Co & -0.443 & 8.528 & 1.06 \\
2 & Co- $5 \mathrm{Gr}$ & -0.437 & 5.933 & 4.35 \\
3 & Co $-10 \mathrm{Gr}$ & -0.436 & 5.910 & 4.41 \\
4 & Co $-15 \mathrm{Gr}$ & -0.435 & 4.912 & 5.31 \\
5 & Co $-20 \mathrm{Gr}$ & -0.419 & 2.425 & 9.89 \\
6 & Co- $-25 \mathrm{Gr}$ & -0.416 & 1.767 & 14.8 \\
\hline
\end{tabular}

after $-0.6 \mathrm{~V}$. The current density remains more or less constant with increase in potential voltage. This phenomenon is due to the formation of oxide layers at the surface of the specimen.

The corrosion characteristics such as corrosion potential ( $\left.E_{\text {corr }}\right)$, current density $\left(I_{\text {corr }}\right)$ and polarization resistance $\left(R_{P}\right)$ are determined by Tafel extrapolation method. From Table 1, it can be understand that corrosion potential $\left(E_{\text {corr }}\right)$ of $\mathrm{Co}-25 \mathrm{Gr}$ nanocomposites $(-0.416 \mathrm{~V}$ vs $\mathrm{Ag} / \mathrm{AgCl})$ is increased than that of pure Co $(-0.443 \mathrm{~V}$ vs $\mathrm{Ag} / \mathrm{AgCl})$, which confirms the increase in corrosion resistance of the composites. The current density of the $\mathrm{Co}-25 \mathrm{Gr}$ nanocomposites $\left(1.767 \cdot 10^{-3}\right.$ $\mu \mathrm{A} / \mathrm{cm}^{2}$ ) has reduced considerably when compared to pure Co $\left(8.528 \cdot 10^{-3} \mu \mathrm{A} / \mathrm{cm}^{2}\right)$.

The decrease in current density decreases the intensity of the corrosion in composite specimens, which in turn reduces the rate of the corrosion. The polarization resistance $\left(R_{P}\right)$ increases with increase in $\mathrm{Gr}$ content in Co-matrix composites, which also substantiate the reduc- 
tion in corrosion rate of the $\mathrm{Co}-\mathrm{Gr}$ nanocomposites.

\subsection{Electrochemical Impedance Spectroscopy Analysis}

The NY-Quist impedance for the Co-25Gr nanocomposite, which is identified as better corrosion composite by potentiometric polarization test, is obtained using electrochemical impedance spectroscopy (EIS). The electron transfer across the composite surface can be measured using charge transfer resistance $R_{c t}$, which is inversely proportional to corrosion rate.

Figure 9 shows the EIS spectra of Co-25Gr nanocomposites, which consist of two semicircles with smaller and larger circles at higher and lower frequency region.

The smaller circle depict the charge transfer resistance $R_{c t 1}$ at the interface of the counter electrode and $\mathrm{NaCl}$ solution and the bigger semicircle begin from the charge transfer resistance $R_{c t 2}$ of the smaller circle because of the electron transfer within the $\mathrm{Co}-\mathrm{Gr}$ nanocomposite and charge transfer at the interface of $\mathrm{Co}-\mathrm{Gr}$ and $\mathrm{NaCl}$ solution.

From the results, it is clear that the Co-25Gr nanocomposite has better corrosion resistance as a result of an increase in charge transfer resistance and a decrease in double layer capacitance. The results of EIS are showed in Table 2.

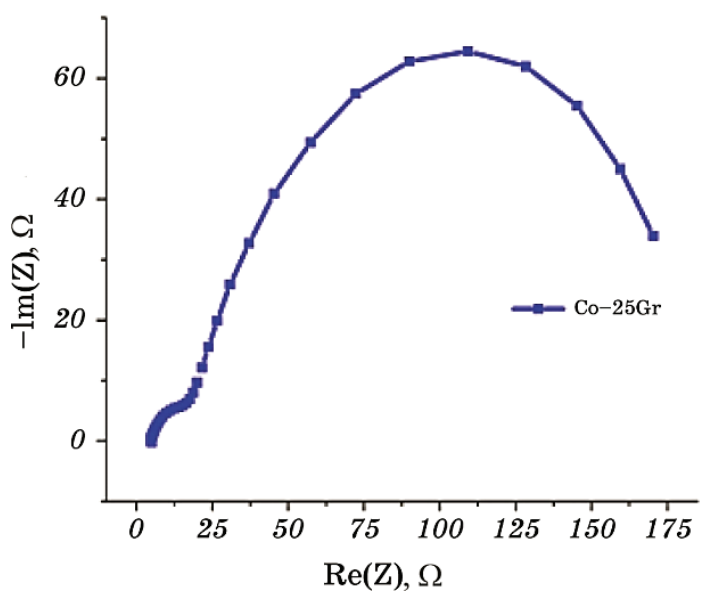

Fig. 9. EIS spectra of Co-25Gr nanocomposites.

TABLE 2. Charge transfer resistance obtained from EIS data fitting by equivalent circuit model.

\begin{tabular}{c|c|c|c|c}
\hline Specimen & $c_{d l 1}, \mathrm{~F}$ & $R_{c t 1}, \Omega$ & $c_{d l 2}, \mathrm{~F}$ & $R_{c t 2}, \Omega$ \\
\hline $\mathrm{Co}-25 \mathrm{Gr}$ & 0.00247 & 20.08 & 0.000247 & 100 \\
\hline
\end{tabular}




\subsection{Immersion Test Analysis}

The weight loss method is employed to study the percentage of weight loss of the composite materials in acidic and brine solutions such as $\mathrm{HCl}, \mathrm{H}_{2} \mathrm{SO}_{4}$ and $\mathrm{NaCl}$ solutions. The composites are immersed in the different normality of above-said solutions for 24 hours. After remov-

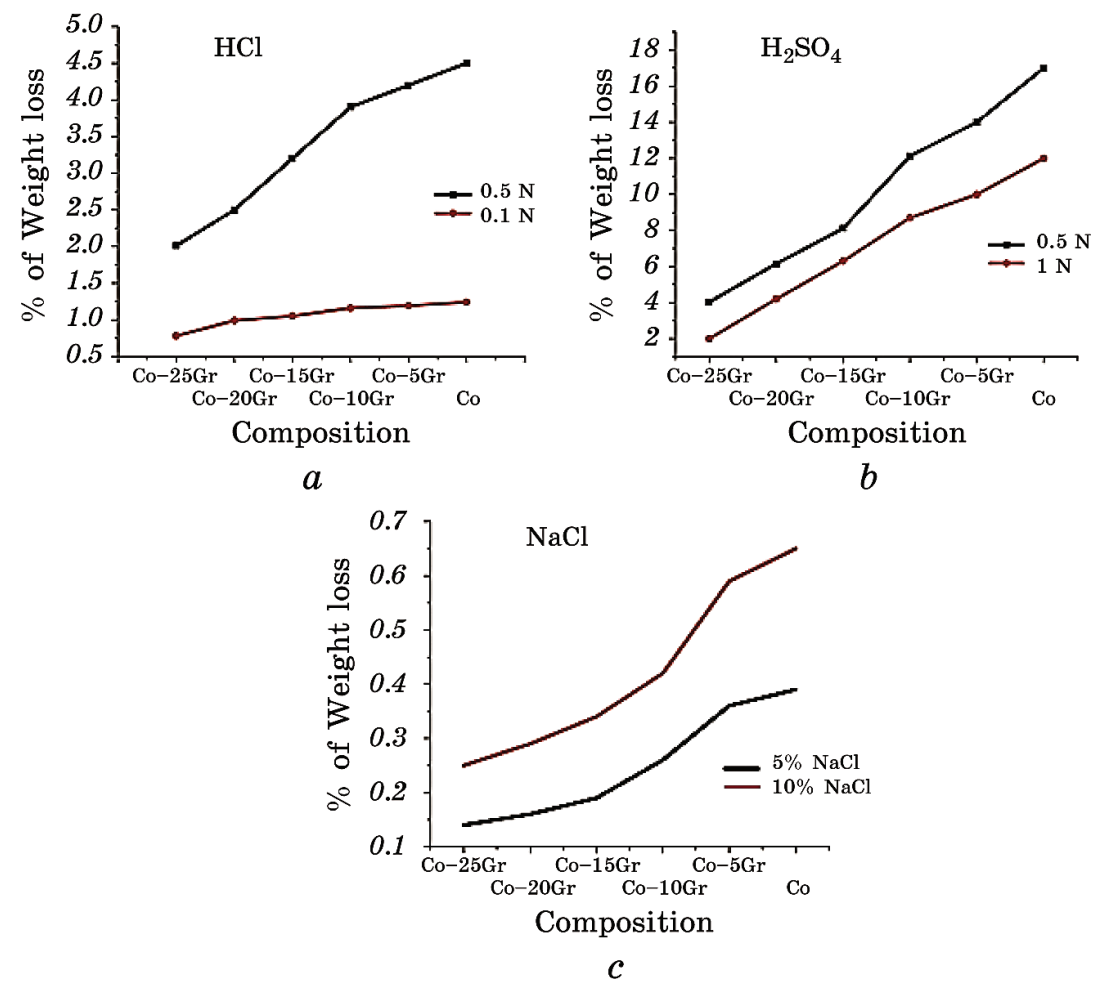

Fig. 10. Graphical representation of weight loss in different media.

TABLE 3. Percentage of weight loss in different media.

\begin{tabular}{c|ccc|c|c|c}
\hline \multirow{2}{*}{ Specimen } & \multicolumn{6}{|c}{ \% of weight loss } \\
\cline { 2 - 7 } & \multicolumn{2}{|c}{$\mathrm{HCl}$} & \multicolumn{2}{c}{$\mathrm{H}_{2} \mathrm{SO}_{4}$} & \multicolumn{2}{c}{$\mathrm{NaCl}$} \\
\cline { 2 - 7 } & $0.1 \mathrm{~N}$ & $0.5 \mathrm{~N}$ & $0.1 \mathrm{~N}$ & $0.5 \mathrm{~N}$ & $5 \%$ & $10 \%$ \\
\hline $\mathrm{Co}-25 \mathrm{Gr}$ & 0.78 & 2.01 & 2 & 4.04 & 0.14 & 0.25 \\
$\mathrm{Co}-20 \mathrm{Gr}$ & 0.99 & 2.5 & 4.2 & 6.15 & 0.16 & 0.29 \\
$\mathrm{Co}-15 \mathrm{Gr}$ & 1.05 & 3.2 & 6.3 & 8.11 & 0.19 & 0.34 \\
$\mathrm{Co}-10 \mathrm{Gr}$ & 1.16 & 3.9 & 8.7 & 12.12 & 0.26 & 0.42 \\
$\mathrm{Co}-5 \mathrm{Gr}$ & 1.19 & 4.2 & 10 & 14 & 0.36 & 0.59 \\
Pure Co & 1.24 & 4.5 & 12 & 17 & 0.39 & 0.65 \\
\hline
\end{tabular}


ing the specimen, it is washed and dried at room temperature. The weights of the specimens are noted before and after the immersion.

The percentage of weight loss is calculated by using the initial and final weight of the specimens. The percentage of weight loss is shown in Table 3 and the graphical representation is shown in Fig. 10.

\section{CONCLUSIONS}

The Co-Gr nanocomposites were prepared by employing high-energy ball mill and warm compacting process. The wear and corrosion resistance of the composites are studied in different conditions. The wear analysis on a pin on disc apparatus shows that $\mathrm{Co}-25 \mathrm{Gr}$ nanocomposite has better wear resistance and coefficient of friction.

The potentiometric polarization analysis shows that the Co-25Gr has improved corrosion resistance in various corrosive media, and the composites also show the signs of passivation due to the presence of $\mathrm{Gr}$ nanoparticles.

The EIS spectra also demonstrate the improvement in corrosion rate, which was due to the increase in charge transfer resistance of the composite material.

The immersion test also reveals that the Co-25Gr nanocomposite has improved corrosion resistance than pure Co. From the findings of this study, it can be concluded that the $\mathrm{Co}-25 \mathrm{Gr}$ nanocomposite has better wear and corrosion resistance.

\section{ACKNOWLEDGEMENTS}

The authors would like to thank the management and principal of K.L.N. College of Engineering, MEPCO Schlenk Engineering and Gandhigram University for their constant encouragement, support and providing all the essential facilities for completing this research work.

\section{REFERENCES}

1. L. M. Vilhena, C. M. Fernandes, E. Soares, J. Sacramento, A. M. R. Senos, and A. Ramalho, Wear, 346-347: 99 (2016).

2. Y. Liu, J. Cheng, B. Yin, S. Zhu, Z. Qiao, and J. Yang, Tribol. Int., 109: 19 (2016).

3. F. Ren, W. Zhu, and K. Chu, J. Mech. Behav. Biomed. Mater., 68: 115 (2017).

4. R. Mousavi, M. E. Bahrololoom, and F. Deflorian, Mater. Design, 110: 456 (2016).

5. R. Liu, J. Yao, Q. Zhang, M. X. Yao, and R. Collier, Mater. Design, 78: 95 (2015).

6. C. Jiang, Y. Xing, F. Zhang, and J. Hao, Int.J. Miner. Metall. Mater., 19, Iss. $7: 657$ (2012). 
7. M. M. H. Bastwros, A. M. K. Esawi, and A. Wifi, Wear, 307, Iss. 1-2: 164 (2013).

8. K. S. Prakash, P. Balasundar, S. Nagaraja, P. M. Gopal and V. Kavimani, J. Magnesium Alloys, 4, Iss. 3: 197 (2016).

9. P. Wang, H. Zhang, J. Yin, X. Xiong, C. Tan, C. Deng and Z. Yan, Wear, 380381: 59 (2017).

10. T. R. Prabhu, V. K. Varma, and S. Vedantam, Wear, 309, Iss. 1-2: 247 (2014).

11. C. Parswajinan, B.V. Ramnath, C. Elanchezhian, S. V. Pragadeesh, P. R. Ramkishore, and V. Sabarish, Procedia.Eng., 97: 513 (2014).

12. Mohammad Sharear kabir, Tamzid lbn Minhaj, Md Delower Hossain, and ASW Kurny, Am. J. Mater. Eng. Technol., 3, Iss. 1: 7 (2015).

13. C. Y. H. Lim, D. K. Leo, J. J. S. Ang, and M. Gupta, Wear, 259, Iss. 1-6: 620 (2005).

14. F. Toptan, A. C. Alves, I. Kerti, E. Ariza, and L. A. Rocha, Wear, 306, Iss. 1-2: 27 (2013).

15. N. Elkhoshkhany, A. Hafnway, and A. Khaled, J. Alloys Compd., 695: 1505 (2017).

16. F. A. P. Fernandes, J. Gallego, C. A. Picon, G. T. Filho, and L. C. Casteletti, Surf. Coat. Technol., 279: 112 (2015).

17. J. H. Qiu and P. H. Chua, Surf. Interface Anal., 28: 119 (1999).

18. T. S. N. Sankara Narayanan, I. Baskaran, K. Krishnaveni, and S. Parthiban, Surf. Coat. Technol., 200, Iss. 11: 3438 (2006).

19. Q. Xu, K. Gao, Y. Wang, and X. Pang, Appl.Surf. Sci., 345: 10 (2015). 